\title{
Entrepreneurial Opportunities for Wind-Energy Markets in Three Emerging Economies
}

\section{Chien-Chi Tseng*}

\begin{abstract}
Wind power is currently perceived as an important source of clean renewable energy and a viable way of decreasing the levels of greenhouse gas emissions. This paper gives an overview of the opportunities and challenges for the emerging wind energy markets in Brazil, China, and South Africa. The specific information on cultural and legal system as well as economic condition in these emerging countries is reviewed briefly. The data from the Global Entrepreneurship Monitor, the World Bank, the Global Wind Report, and other public online sources are applied to this study. A practical framework is constructed to explore the relationships among entrepreneurial opportunities of wind energy businesses and their benefits, costs, and risks in these countries. The purpose of this study is to review a practical model that positions the benefits, costs, and risks as well as opportunities and challenges in the three emerging countries. This study begins by exploring the three selected countries in the efficiency-driven economies. Then, this study attempts to compare the wind energy markets in the three countries and highlighting the importance of benefits, costs, and risks for these emerging markets. Furthermore, the discussions for characteristics of opportunities and challenges are performed for the three selected nations. Finally, conclusions and implications are generated for the further study. From this research, it is concluded that there are different perspectives of wind energy business development in Brazil, China, and South Africa. Also, enhancing entrepreneurial opportunities is a good way to overcome the challenges for new business development in the emerging economic markets.
\end{abstract}

Keywords: emerging economies, efficiency-driven countries, wind-energy markets, renewable sources, entrepreneurial opportunity.

\footnotetext{
* Chien-Chi Tseng, Ph.D., Assistant Professor, Morgan State University, Department of Business Administration, 1700 East Cold Spring Lane, Baltimore, MD 21251, chien-chi.tseng@morgan.edu.
} 


\section{INTRODUCTION}

The increase in global investment and cross-border entrepreneurship during the century reflects the growing opportunity of national economies. The entrepreneurial activity has played a central role in the process of economic change by creating new businesses and services in the global communities. Thus, globalization has significantly influenced entrepreneurial opportunity and performance (Chrysostome, 2010). Kelley, Bosma, and Amorós (2011) cite the survey results from the Global Entrepreneurship Monitor (GEM) to emphasize the positive impact of entrepreneurial activity on economic growth, innovation, and internationalization, within and across economies.

Since entrepreneurship is concerned with the discovery and exploitation of profitable opportunities (Shane and Venkataraman, 2000), it has followed certain waves in its own development across the world, much like other economic processes. The decades of the 70's and 80's represent one of these waves of entrepreneurial activities - during this time, the entrepreneurial concept and effects reflected the business mindset (Lumpkin, 2011) and it made significant contributions to the economy and society (Landstrom, 2005). These entrepreneurial effects lead to an increase of productivity in labor and capital, which enhance economic growth (Hill, 2011); and to the development of new management paradigms embedded in business strategies and practices (Timmons and Spinelli, 2009). The twenty-first century faces new challenges in the economic and management system as the global entrepreneurial age develops (Drucker, 2001). Based on Asif and Muneer's (2007) review for renewable and sustainable energy, these challenges include the quest to reduce greenhouse gas emissions associated with traditional (e.g., fossil fuel-based) power generation, and to seek sustainable, clean, renewable energy alternatives such as wind power. This specific challenge presents an opportunity for entrepreneurs.

However, although researchers have made many efforts in recognizing the importance of entrepreneurial opportunity (e.g., Ardichvili, Cardozo, and Ray, 2003; McMullen, Plummer, and Acs, 2007; Singh, 2001) and challenges (e.g., Brush, Greene, Hart, and Haller, 2001; Rodie and Martin, 2001), little existing theory or research has been involved in the discussion of entrepreneurial opportunity and challenge for wind energy business. In particular, the connection for entrepreneurial opportunity with wind energy business in the emerging market countries has not been discussed in the existing international business and entrepreneurship literature yet. Therefore, the opportunity of wind energy business will depend on entrepreneurship, offering quality products and services at affordable prices. This is a good way to promote entrepreneurial activity in the emerging market countries (Nonis and Relyea, 2012). 
Accordingly, the purpose of this study is to examine wind energy markets and related entrepreneurial opportunities within the selected emerging economies and to explore the practical framework relationships for developing wind turbine business in the emerging country contexts. This paper approaches a cross-border initiative in entrepreneurship in the emerging economies. Given the broader context of greener energy, global warming, and the often-mentioned, but rarely investigated role of emerging economies, we select three emerging wind markets for study. This study begins by exploring the theoretical backgrounds in defining entrepreneurial opportunity and discussing the three selected emerging markets in efficiencydriven economies. Then, this study attempts to construct the research model and hypotheses. In addition, research methodology and results are explored with comparing the wind energy markets in the three countries and highlighting the importance of benefits, costs, and risks for these emerging markets. Furthermore, the discussions of characteristics of opportunities and challenges are offered for the three selected nations. Finally, conclusions and implications are generated for practice and further study.

\section{THEORETICAL BACKGROUNDS}

Emerging multinationals' internationalization process often gives entrepreneurs access to new customers, innovation, and technological hubs as well as several possibilities to experience new things that were not available or feasible in their local markets (Zahra, Abdelgawad, and Tsang, 2011). Thus, researchers have recently shifted attention away from approaches that focus on identifying those people in society who prefer to become entrepreneurs towards understanding the nexus of enterprising development and valuable opportunities in the emerging country context (Venkataraman, 1997). This new focus has required scholars to explain the role of opportunities in the process of entrepreneurship (Eckhardt and Shane, 2003). Accordingly, Zahra et al. (2011) point to the fact that exploiting these opportunities in the new context requires firms to build an entrepreneurial capability that allows them to simultaneously leverage their inherent capabilities while stretching to build new ones in the emerging markets.

For the past decades, the dominant theories in entrepreneurship have sought to explain entrepreneurship as a function of the types of people engaged in entrepreneurial activity and, as a result, have largely overlooked the opportunity for entrepreneurship (Eckhardt and Shane, 2003). An opportunity focus therefore necessitates consideration of the process of entrepreneurship (Rasmussen et al., 2011) with benefit, risk, and cost for the wind energy business in the global emerging environment. Entrepreneurial 
opportunity involves not only technical skills like financial analysis and market research, but also less tangible forms of creativity, team building, problem solving, and leadership (Hindle, 2004). Based on Shane and Venkataraman (2000), entrepreneurial opportunity is defined as a situation in which new goods, services, raw materials, markets, and organizing methods can be introduced through the formation of new means, ends, or means-ends relationships. This definition suggests that identifying and selecting right opportunities for new businesses are among the most important abilities of a successful entrepreneur (Ardichvili et al., 2003).

Entrepreneurial opportunity recognition is the ability to identify institutional theory and practice in which new goods, services, raw materials, markets, and organizing methods can be introduced through the formation of new means, ends, or means-ends relationships (Eckhardt and Shane, 2003). It is our thought that entrepreneurial opportunity recognition is also fundamental to institutional theory. Institutions are defined as regulative, normative, and cognitive structures and activities that provide stability and meaning to social behavior (Scott, 1995). Institutions govern societal transactions in the areas of politics (e.g. corruption, transparency), law (e.g., economic liberalization, regulatory regime), and society (e.g., ethical norms, attitudes toward entrepreneurship) (Peng, Wang, and Jiang, 2008). Therefore, integrating the notion of opportunity-recognition into research on entrepreneurship would add an important dimension to the institutional theory and provide a useful and interesting way of explaining the enterprise development in the international business environment.

The specific emerging wind energy markets are selected according to the criteria of national competitiveness in the emerging country study. The matching criteria of the national competitiveness for the three selected countries include Brazil, China, and South Africa. These criteria offer significant opportunities for entrepreneurship compared with well-established markets. "Competitiveness" involves static and dynamic components and is defined broadly as that "set of institutions, policies, and factors that determine that level of productivity of a country" (World Economic Forum, 2010) and productivity in turn provides prosperity and well-being (Frankenstein, 2011). There are many determinant components driving productivity and competitiveness and "these components are grouped into 12 pillars of economic competitiveness" (World Economic Forum, 2010, pp. 4-8):

1) Institutions: the institutional environment in the emerging markets.

2) Infrastructure: Extensive and efficient infrastructure of the emerging markets.

3) Macroeconomic environment: the stability of the macroeconomic environment in an emerging market. 
4) Health and primary education: a healthy workforce and good quantity and quality of basic education in the emerging markets.

5) Higher education and training: quality higher education and training is crucial for emerging markets.

6) The emerging markets with efficient-goods markets.

7) Labor market efficiency: the efficiency and flexibility of the labor market in the emerging markets.

8) Financial market development: the well-functioning financial sector for economic activities.

9) Technological readiness: an important element for firms to compete and prosper in the emerging markets.

10) Market size: the size of the market affects productivity.

11) Business sophistication: to enhance a nation's competitiveness, and

12) Innovation: is particularly important for emerging markets.

Economic development involves change and the entrepreneur becomes the best agent for this change (Acs and Virgill, 2010). In such a global economic environment under uncertainty and challenges, it is more important than ever for the emerging countries to put into place the fundamentals underpinning economic growth and development, to understand the key factors determining economic growth, and to explain why some emerging countries are more successful than others in raising entrepreneurial opportunities for their respective populations (World Economic Forum, 2010). Economic development in the emerging countries implies a process of structural transformations leading to an overall higher growth trajectory (Brinkman, 1995).

According to the World Economic Forum (2010), three different stages of economic development influence the perceived entrepreneurial opportunities and capabilities in the different countries. The first stage is factor-driven economy. In this stage, countries compete based on their factor endowments: primarily unskilled labor and natural resources (Porter, 1990). Maintaining competitiveness at this economic development stage hinges primarily on well-functioning public and private institutions, well-developed infrastructure, a stable macroeconomic environment, and a healthy workforce that has received at least a basic education (World Economic Forum, 2010). In the second stage of efficiency-driven economy, entrepreneurs with high aspirations fare better in countries with a stable economic and cultural climate, in addition to other well-developed institutions. At this point, entrepreneurial opportunities are increasingly driven by higher education and training, efficient goods markets, well-functioning labor markets, developed financial markets, the ability to harness the benefits of existing technologies, and a large domestic or foreign market (World Economic Forum, 2010). In the third stage of innovation-driven economies, knowledge is prevalent but labor 
is expensive. Entrepreneurship-specific opportunities become the levers that drive dynamic, innovation-oriented behavior, while the foundation of basic requirements and efficiency enhancers needs to be maintained (Kelley et al., 2011).

Unlike "factor-driven" countries which are mainly characterized by agricultural production and natural resource extraction, the features of scale and capital in efficiency-driven countries are important to the context of wind power development. In many cases, technology is imported from "innovation-driven" countries, which also augments the opportunity for global entrepreneurship in this sector. Thus, we narrowed our scope to the list of "efficiency-driven" countries. Economic growth in these countries is connected to increasing economies of scale, the provision of support, opportunities for entrepreneurial activities, and the development of the banking sector as a backbone for capital-intensive organizations.

Given the widely varying wind patterns across the world, we decided to extend the geographic scope as broadly as possible. The regional groupings in the "efficiency-driven" category are used to achieve this geographic dispersion: Sub-Saharan Africa and North Africa (only South Africa and Tunisia); Latin America and the Caribbean (10 countries including Argentina, Brazil, Mexico and Uruguay); Eastern Europe and Asia Pacific (6 countries including Croatia, Hungary, Romania, Malaysia, China, and Taiwan).

\section{RESEARCH MODEL AND HYPOTHESES}

This research focuses on distinguishing the relationships between entrepreneurial opportunity and wind energy business in the three representative emerging countries. What does this approach look like to develop wind energy business with entrepreneurial opportunity in the three emerging economies? How are the relationships between entrepreneurial opportunity and wind energy business benefits, costs, and risks in the three emerging countries? The research argues that this fundamental underlying mechanism is embodied within the hypothesized framework and the research concepts of entrepreneurial opportunity, business benefits, costs, and risks in this study. 
Table 1. Indicators of GEM Entrepreneurship Activity in the Selected Countries

\begin{tabular}{lccc}
\hline GEM Entrepreneurship Activity Indicators in 2010 & Brazil & China & $\begin{array}{c}\text { South } \\
\text { Africa }\end{array}$ \\
\hline $\begin{array}{l}\text { Total early-stage Entrepreneurial Activity (TEA) (\%) } \\
\text { Total early-stage Entrepreneurial Activity for }\end{array}$ & 17.5 & 14.4 & 8.9 \\
$\begin{array}{l}\text { Female Working Age Population (\%) } \\
\text { Total early-stage Entrepreneurial Activity for Male }\end{array}$ & 16.4 & 12.4 & 8.1 \\
Working Age Population (\%) & 18.6 & 16.4 & 9.6 \\
Improvement-Driven Opportunity Entrepreneurial & 46 & 34 & 31 \\
Activity (\%) & 31 & 42 & 36 \\
Necessity-Driven Entrepreneurial Activity (\%) & 15.3 & 13.8 & 2.1 \\
Established Business Ownership Rate & 11.8 & 10 & 3.9 \\
New Business Ownership Rate (\%) & 5.8 & 4.6 & 5.1 \\
Nascent Entrepreneurship Rate (\%) & & & \\
\hline
\end{tabular}

Note: The numbers in this table represent the percentage of each related entrepreneurship activity. The higher number has the better comparing percentage data in the indicators. The columns with shading have the best comparing data in the indicators.

Source: Global Entrepreneurship Monitor Report (2010).

Within these regional groupings, we selected emerging economies with the highest GDP in recognition of the fact that higher economic activity, especially in terms of large projects, does indirectly benefit entrepreneurial activity - as is borne out by comparing the Total Early-Stage Entrepreneurship Activity (TEA) rates from GEM report. Table 1 demonstrates the comparative information of the entrepreneurial activity and opportunity indicators in the three selected countries - Brazil, China, and South Africa. In the GEM report, several indicators are measured for the extent to which people think there are good opportunities for starting a business and their capabilities for doing so (Kelley et al., 2011). Those indicators include TEA, TEA for Male and Female Working Age Population, Improvement-Driven and NecessityDriven Opportunity Entrepreneurial Activity, and New and Established Entrepreneurship Rate. The numbers in Table 1 represent the percentage of each related entrepreneurship activity. The higher number has the better comparing percentage data in the indicators.

Entrepreneurial opportunity is a benefit development activity that involves the discovery, evaluation, and exploitation of opportunities to introduce new goods and services, ways of organizing, markets, processes, and raw materials through organizing efforts that previously had not existed (Shane and Venkataraman, 2000; Venkataraman, 1997). Drawing on the above contributions to the activities of benefit increase in the emerging economies, entrepreneurial opportunity is identified as the manifest ability 
and willingness of nations (Wennekers and Thurik, 1999) to perceive new economic opportunities and to introduce their ways of seizing these opportunities into the global market in the face of uncertainty (Bjørnskov and Foss, 2008).

Entrepreneurs are recognized as the single most important player in a modern economy (Lazear, 2002) because they in many ways personify market forces, and it is expected that entrepreneurs shall be the central figures in economics (Bjørnskov and Foss, 2008). Opportunities, in the sense of entrepreneurship and management benefits, are treated as a construct that is manifested in entrepreneurial action-investment, creating new organizations, bringing products to market (Klein, 2008), and develop approaches for national growth.

Therefore, we take a viewpoint that opportunities can exist independently of the different benefit development levels (Shane and Venkataraman, 2000). In any circumstance, characteristics of size of economy, government incentives, or wind resource capability may create different benefits for wind-energy entrepreneurship (Stephan and Uhlaner, 2010) in the emerging markets. Accordingly, the first hypothesis is provided:

Hypothesis 1: Entrepreneurial opportunities have a significant relationship with wind energy market benefits in the emerging economies.

Entrepreneurial opportunities are increasingly recognized as the main driver of economic growth and prosperity at local, national, and regional levels, and worthy of considerable support and cost investment in infrastructure (Floyd and McManus, 2005), technology improvement, and human resource quality. Klein (2008) points out these opportunities include creating a new firm or starting a new business arrangement, introducing a new product or service, or developing a new method of production. These activities are significantly influenced by entrepreneurial costs.

Moreover, based on Kelley et al. (2011) in the 2010 Global Report of Global Entrepreneurship Monitor, if the country in general has positive attitudes toward entrepreneurship, this will generate economic support, financial resources and costs, networking benefits and various other forms of assistance to current and potential entrepreneurs. Therefore, the costs toward entrepreneurship are affected by environmental supports and personality traits (Chen and Lai, 2010) and the enterprise development can benefit from people who are able to recognize valuable business costs (Kelley et al., 2011), and who perceive they have the required skills to reduce the costs in the international operation. Therefore, the second hypothesis is provided: 
Hypothesis 2: Entrepreneurial opportunities have a significant relationship with wind energy market costs in the emerging economies.

The concept of risk-taking and its linkages with the construct of entrepreneurial opportunity have been reasonable to capture. As a result, it has been fair to explain why entrepreneurs rush in to take advantage of opportunities that others fail to see or act upon (Palich and Bagby, 1995). According to Palich and Bagby (1995), entrepreneurs may not think of themselves as being any more likely to take risks than non-entrepreneurs, but they are nonetheless predisposed to cognitively categorize business situations more positively. In this study, risks for engaging a new business include the corruption risk, freedom and rule of law risk, and legal systems and protection risk. These risks challenge entrepreneurs to identify and exploit business opportunities, even when they are distracted by the perceived high risk of these ventures (Palich and Bagby, 1995). Consequently, the third hypothesis is offered:

Hypothesis 3: Entrepreneurial opportunities have a significant relationship with wind energy market risks in the emerging economies.

\section{ReSEARCH Methodology}

This study comprises a comparative analysis of the political, legal, and economic systems in the selected countries as a means to understand the influence of these systems on doing business in the respective countries on a broad level. Relevant data were assembled from several secondary sources including: the World Bank, the World Trade Organization, the World Economic Forum, the International Monetary Fund, the United Nations Environment Program, Transparency International, the Freedom House, the Global Wind Energy Council, Global and National Wind Power Atlases, National Wind Energy Associations, and Government agencies like Ministries of Mines and Energy, and Environment. Also, correlation analysis is used to verify hypothesized relationships between entrepreneurial opportunities and wind energy business benefits, costs, and risks in the selected emerging countries.

We compare the countries from the perspective of a start-up in the wind energy business seeking to establish operations in a foreign country. This perspective is relevant considering that the transportation of turbine blades to wind sites, for example, presents a cost challenge if the blades are not manufactured sufficiently close to the sites where they will be installed. Therefore, entrepreneurs in the wind energy business may need to 
evaluate international locations that will optimize the need to achieve both production efficiency and market responsiveness. In this regard, we extend our comparative analysis of the broader business context to wind-specific entrepreneurial circumstances and evaluate the attractiveness or otherwise of making wind power investments within the selected markets. Thus, we discuss the issues of opportunities and challenges in the entrepreneurial process, and offer insights into how wind energy businesses might successfully be involved in the three selected emerging markets.

\section{RESEARCH RESULTS}

This selection process allowed Brazil, China, and South Africa to represent different regions in the world within the efficiency-driven category, all with energy security concerns and with emerging markets in the wind sector. A cross country comparison matrix of national statistical information in the wind energy industry by these three countries is illustrated in Table 2 .

Table 2. Indicators of Benefits, Costs, and Risks of Doing Business in Three Countries

\begin{tabular}{|c|c|c|c|c|}
\hline Item & Indicators (2010) & Brazil & China & South Africa \\
\hline 1 & Population (total, million) & 194.9 & 1338.3 & 49.9 \\
\hline 2 & Population growth (annual \%) & 0.9 & 0.50 & 1.4 \\
\hline 3 & GDP (current US\$ billion) & 2087.9 & 5878.6 & 363.7 \\
\hline 4 & GDP growth (annual \%) & 7.5 & 10.3 & 2.8 \\
\hline 5 & GDP per capita (current US\$) & 10710.1 & 4392.6 & 7275.3 \\
\hline 6 & $\begin{array}{l}\text { Total Installed Wind Power } \\
\text { Capacity (MW) }\end{array}$ & 931 & 42287 & 8 \\
\hline 7 & $\begin{array}{l}\text { Wind energy price with government } \\
\text { subsidies (US\$ / MWh) }\end{array}$ & 65.3 & 94.0 & 30.5 \\
\hline 8 & $\begin{array}{l}\text { Number of Wind Turbine } \\
\text { Manufacturers ( } 5 \mathrm{MW} \text { or more) }\end{array}$ & 4 & 7 & 0 \\
\hline 9 & $\begin{array}{l}\text { Ease of doing business index (1= most } \\
\text { business-friendly regulations) }\end{array}$ & 127 & 79 & 34 \\
\hline 10 & $\begin{array}{l}\text { Ease of obtaining credit } \\
\text { (Rank out of } 183 \text { countries) }\end{array}$ & 89 & 65 & 2 \\
\hline 11 & $\begin{array}{l}\text { Ease of registering property } \\
\text { (costs as \% property value) }\end{array}$ & 2.7 & 4 & 8.8 \\
\hline 12 & $\begin{array}{l}\text { Ease of enforcing contracts } \\
\text { (cost as \% of claim) }\end{array}$ & 16.5 & 11.1 & 33.2 \\
\hline 13 & $\begin{array}{l}\text { Credit depth of information index } \\
\text { [0 (low) to } 6 \text { (high)] }\end{array}$ & 5 & 4 & 6 \\
\hline 14 & Taxation (\% of profits) & 69 & 63.5 & 30.5 \\
\hline 15 & Inflation, consumer price (annual \%) & 5.0 & 3.3 & 4.3 \\
\hline
\end{tabular}




\begin{tabular}{|c|c|c|c|c|}
\hline 16 & $\begin{array}{l}\text { Time required to start } \\
\text { a business(days) }\end{array}$ & 120 & 38 & 22 \\
\hline 17 & $\begin{array}{l}\text { Strength of Investor Protection } \\
\text { [0 (low) to } 10 \text { (high)] }\end{array}$ & 5.3 & 5 & 8 \\
\hline 18 & $\begin{array}{l}\text { Protecting Investors } \\
\text { (Rank out of } 183 \text { countries) }\end{array}$ & 74 & 93 & 10 \\
\hline 19 & $\begin{array}{l}\text { Corruption index-1 } \\
\text { (Rank out of } 183 \text { countries) }\end{array}$ & 69 & 73 & 54 \\
\hline 20 & $\begin{array}{l}\text { Corruption index-2 } \\
\text { [0 (poor) to } 10 \text { (good)] }\end{array}$ & 3.7 & 3.6 & 4.5 \\
\hline 21 & $\begin{array}{l}\text { Anti-corruption efforts } \\
{[-2,5 \text { (weak) to } 2,5 \text { (strong)] }}\end{array}$ & -0.06 & -0.52 & 0.1 \\
\hline
\end{tabular}

Note: The columns with shading have the best comparing data in the indicators. Items $1-8$ belong to the category of Benefits; Items $9-14$ belong to the category of Costs; Items $15-21$ belong to the category of Risks.

Source: Global Wind Energy Council (2011); Transparency International (2009); World Bank (2010); and World Economic Forum (2010).

Table 2 compares the selected countries in terms of indices that describe the size and potential growth of the market, risks and challenges of doing business within and across borders, and the costs associated with the legal framework.

Tables 1 and 2 appear to highlight the entrepreneurial opportunities as well as benefits, costs, and risks in different respects for the markets of Brazil, China, and South Africa. The significantly easier access to credit in South Africa is an advantage for investors. Also, South Africa's membership in the Southern African Development Community (SADC) and its aggressive efforts to establish a business presence in several African countries increase the market size that must be taken into account in this analysis. Brazil is clearly committed to developing renewable energy. However, the exposure to competition from outsiders entering these markets may be unhealthy for start-ups in this industry because they are not well competitive with strong outsiders. This is a similar situation for China which already has large players (4 of the 10 largest manufacturers) in the market. Table 3 presents positive and negative factors extending the comparison of quantitative data presented in Tables 1 and 2. 
Table 3. Cross-Country Comparison of Qualitative Factors Affecting Attractiveness of Wind Energy Business

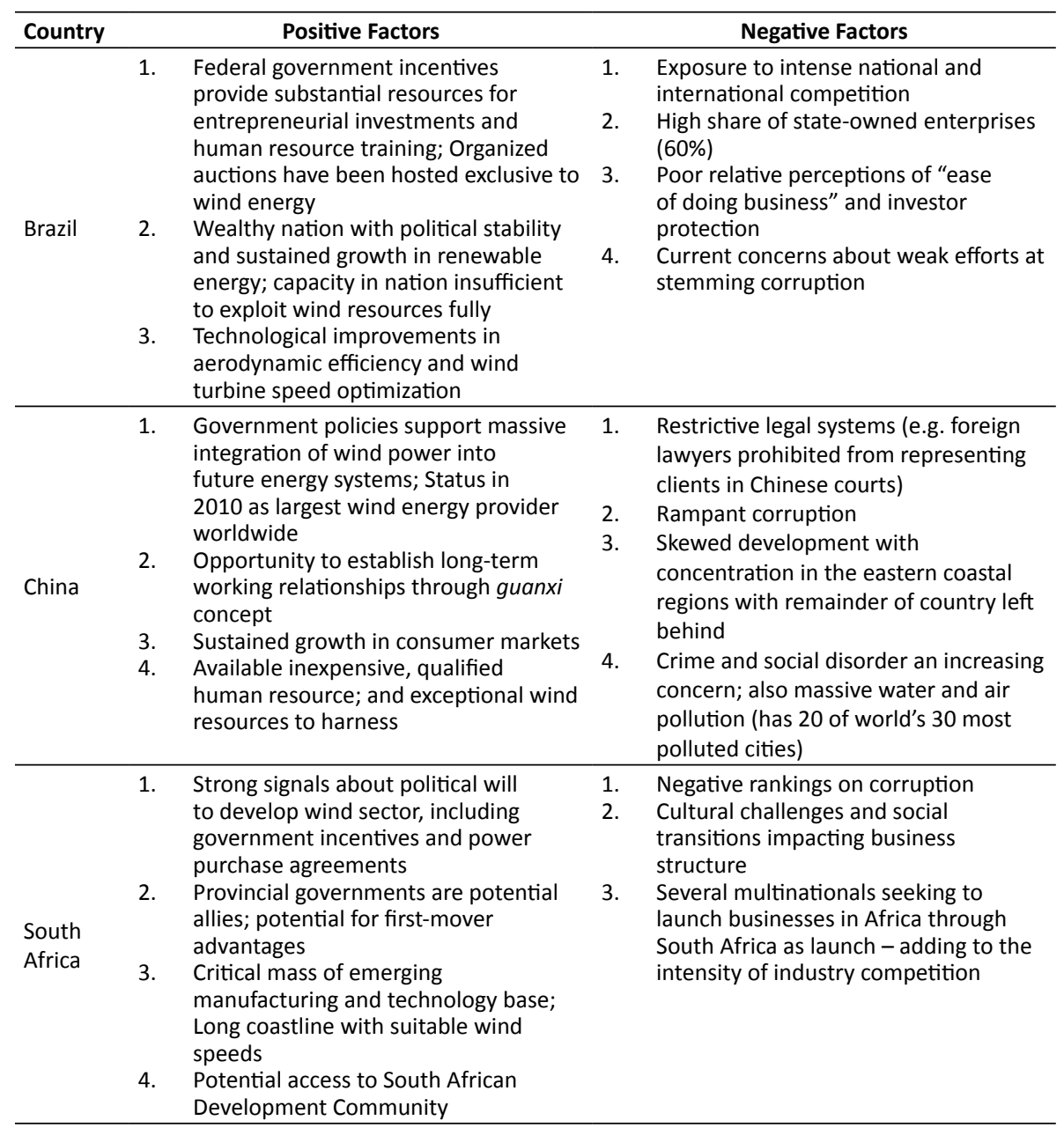

Source: Global Wind Energy Council (2011); Global Entrepreneurship Monitor Report (2010); and World Economic Forum (2010).

Table 4 shows the correlation matrix of 23 indicators for the three wind energy emerging markets. These 23 indicators are categorized into four groups:

Entrepreneurial opportunities (4 indicators - Total Early-Stage Entrepreneurial Activity, Established Business Ownership Rate, New Business Ownership Rate, and Nascent Entrepreneurship Rate);

Wind energy market benefits (7 indicators - Population, Population Growth, GDP Growth, GDP per Capita, Total Installed Wind Power Capacity, 
Wind Energy Price with Government Subsidies, and Number of Wind Turbine Manufacturers);

Wind energy market costs (6 indicators - Ease of Doing Business Index, Ease of Obtaining Credit, Ease of Registering Property, Ease of Enforcing Contracts, Credit Depth of Information Index, and Taxation); and

Wind energy market risks ( 6 indicators - Inflation: Consumer Price, Time Required to Start a Business, Strength of Investor Protection, Protecting Investors, Corruption Index, and Anti-Corruption Efforts)

From the analysis results in Table 4, correlations among four indicators of the group of entrepreneurial opportunities are significant (ranging from 0.53 to 0.98). Correlations among seven indicators of the group of wind energy market benefits are significant (ranging from 0.21 to 0.99). Correlations among six indicators of the group of wind energy market costs are significant (ranging from -0.82 to 0.78 ). Correlations among six indicators of the group of wind energy market risks are significant as well (ranging from -0.91 to 0.89).

In addition, the correlations between the indicators of entrepreneurial opportunities and wind energy market benefits are found to indicate a significant relationship (ranging from 0.32 to 0.85 ). The correlation between the indicators of entrepreneurial opportunities and wind energy market costs are also found to indicate a significant relationship (ranging from -0.94 to 0.98). Similarly, the indicators of entrepreneurial opportunities and wind energy market risks show a significant relationship (ranging from -0.97 to 0.93). 


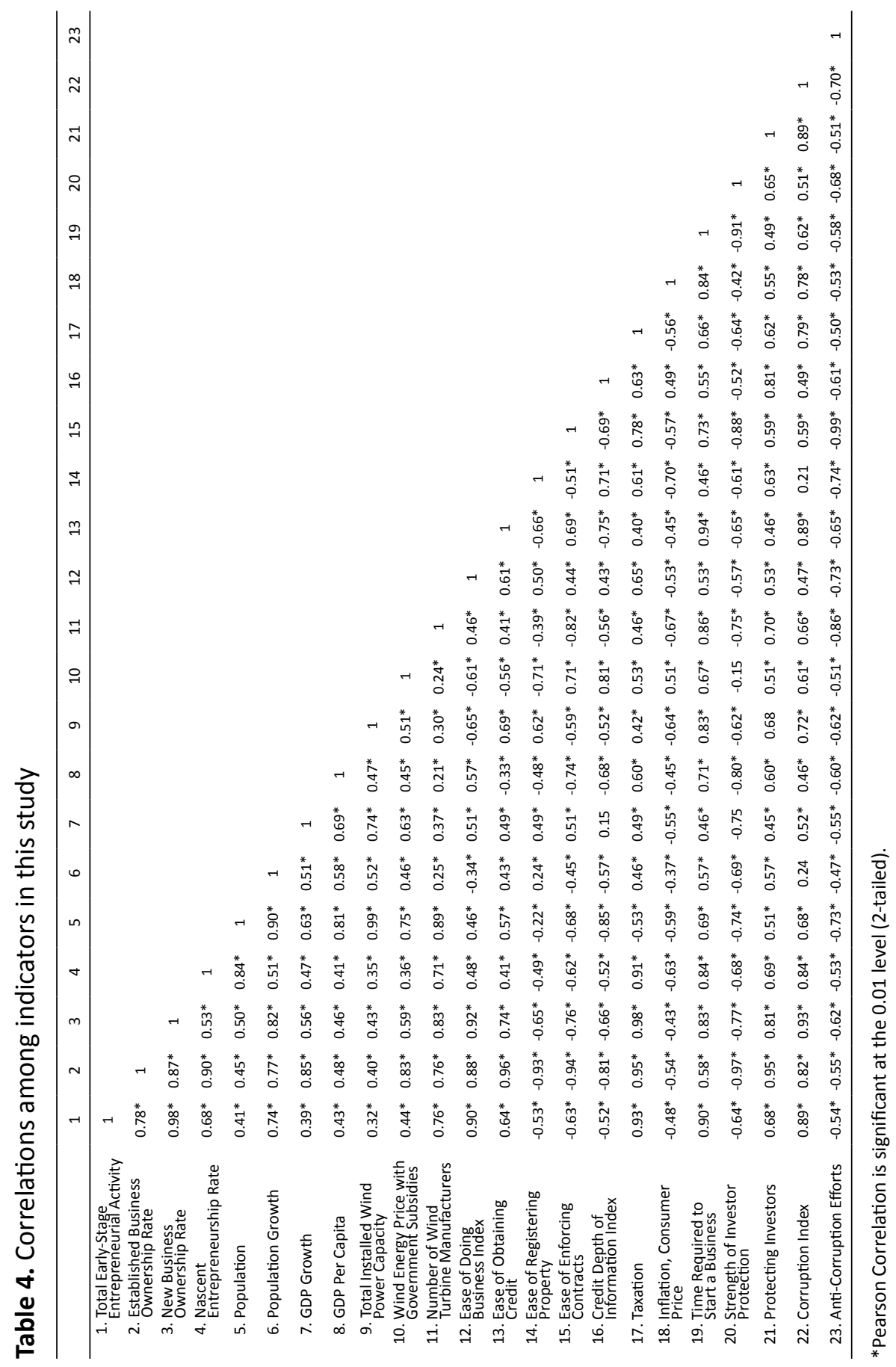




\section{Discussions}

Through wind energy market comparison in the three selected emerging countries, this study not only provides a new direction for wind energy development research in the emerging markets, but also generates an interesting discussion for international business and entrepreneurship. We believe that strengthening entrepreneurial opportunity would be a wise way to achieve wind energy market development in the emerging countries. Through the correlation analysis, the study found that three hypotheses are well verified. Correlations among the four indicators of entrepreneurial opportunity are significant. Similarly, correlations among the indicators for each group of wind energy market benefits, costs, and risks are significant. In addition, the correlations between the different groups of entrepreneurial opportunity with wind energy market benefits, wind energy market costs, and wind energy market risks are also found to indicate significant relationships. The findings from this study suggest that entrepreneurial opportunity can be viewed as an important influencing factor for wind energy business development in the emerging economies.

The next section provides additional insights into the business environment of various countries.

\section{Brazil}

Brazil is on the forefront of alternative energy projects with a voluntary commitment to reduce its greenhouse gas emissions by 2020 (The World Bank, 2011); with the national consumption of ethanol in automobiles surpassing gasoline consumption in 2008; and with 45 percent of energy needs supplied from renewable sources (Ministry of Mines and Energy, 2008a). Development of wind power is one positive spillover effect of the alternative energy projects; and has been aided by political will expressed through state incentives, the improvement of aerodynamic efficiencies and the optimization of wind turbine speeds (Marques et al., 2003). Government support frameworks include the Alternative Sources Incentive Program which seeks to promote the diversification of the Brazilian energy matrix through joint ventures in wind, biomass and small hydroelectric systems. However, much interest in wind power has been concentrated in the Northeastern region in line with the fact that this region has the largest wind power potential (Rosas et al., 2004). Furthermore, there has been an increase in the development of diverse entrepreneurial entities in this region (Brasil, 2010), providing a ready application for energy generation.

For foreign investors in the wind sector, the opportunities and challenges of engaging the wind power business have been summarized in Table 3. 
Based on the work of de Araújo and de Freitas (2008), Pereira et al. (2011), and on other sources listed earlier, there exists a demand gap that foreign investors can exploit in this market. The high levels of taxation are currently being addressed, and entrants need to have a long-term perspective on their involvement.

\section{China}

China became the largest wind energy provider worldwide, with the installed wind power capacity reaching $41.8 \mathrm{GW}$ at the end of 2010 (Kroldrup, 2010). According to the Global Wind Energy Council (2011), the development of wind energy in China, in terms of scale and rhythm, is absolutely unparalleled in the world. The large land mass and long coastline provides exceptional wind resources for China, which can be harnessed to fuel growth in the economy (Gow, 2009). According to Li et al. (2010), the potential for exploiting wind energy in China is enormous, with a total exploitable capacity for both landbased and offshore wind energy of around 700-1,200 GW. The need for alternative energy sources in China is great, given that it has now become the world's largest energy consumer relying on coal to supply about 70 percent of its energy needs (Swartz and Oster, 2010). Nevertheless, the larger Chinese wind turbine manufacturers have also entered the international competition for large-scale wind power equipment - developing $5 \mathrm{MW}$ or larger turbines (Global Wind Energy Council, 2011) - and expanding into overseas markets (Lema and Ruby, 2006) with the support of several component manufacturers (Federico, 2009).

China is a unitary state that has experienced a drive to establish a functioning legal system, and promulgated over 300 laws and regulations from the late 1970s to the mid-1990s (Potter, 1999). As a result of a pending trade war with United States over violations of intellectual property right of U.S. corporations in the early 1990s, China's trademark law has been modified, and now offers significant protections to foreign trademark owners. Even though China has maintained its unity and domestic stability, and has achieved rapid economic growth and a higher standard of living for the overwhelming majority of its people, there are challenges for its current political situation. Besides the challenge of Taiwan's de facto independence, growing urban unemployment, rising crime, social disorder, and corruption challenge the government's ability to maintain stability (Oksenberg, 2001).

Businesses intending to invest in China may fare poorly unless they get sound advice. Obtaining good advice has much to do with "guanxi" which literally means "relationship(s)" (Tsang, 1998). It is a concept essential to one's effective functioning in the Chinese society because the Chinese often 
feel obligated to do business with their friends first (Leung and Wong, 2001). Existing pricing policies, however, affect the level of active investment by developers ( $\mathrm{Li}$ et al., 2010). If a foreign company has the financial muscle to counter the entry barriers, including some technological advantages in turbine design, for example, then a long-term approach to entering the Chinese market will be desirable.

\section{South Africa}

South Africa is the dominant economic player within the Southern African Development Community. It is also viewed as a gateway to many other African countries. According to the World Bank (2011), South Africa is the best African country in which to do business, next only to Mauritius by ranking. The International Monetary Fund (IMF) forecasts that economic growth rates in Africa could surpass that of Asia in the next five years, noting that over the ten years preceding 2010, six of the world's ten fastest growing economies were in Africa. The strong growth of Foreign Direct Investment in Africa, especially from China, can be seen as signaling the readiness of Africa to do business with the world. In this regard, a higher incidence of industrial investments will put an even greater strain on the existing limited energy resources, and strengthen the case for supply-side interventions on the continent. Furthermore, Africa's population exceeded one billion in 2009, is growing at an average rate of 2.4 percent, and is expected to double by the year 2050 (United Nation Environment Program, 2010). McKinsey (2010) put the number of middle class households, defined as those with annual incomes of at least $\$ 20,000.00$, in Africa at fifty million, as many as in India.

Within this larger context, South Africa has a growing economy, a critical mass of industries and an associated need for reliable sources of electricity (Kirsten and Rogerson, 2002). Its increasing industrialization and the robust growth of industries like mining, automobile assembly, metalworking, machinery, and textiles has placed unprecedented demands on its energy resources (Kirsten and Rogerson, 2002). A severe electricity crisis interrupted economic development in 2007, necessitating the import of several billion KW of power to meet demand (Von Schnitzler, 2008). The commitment of the government to energy security was expressed in the 2011 State of the Nation address and followed the 2010 release of the country's Integrated Resource Plan (IRP). The IRP seeks to generate $10,000 \mathrm{GW}$ of electricity from alternative sources by 2013 , and includes private renewable energy suppliers (Von Schnitzler, 2008). According to the United Nations Environment Program (2011), wind power constitutes about 74 percent of the potential to produce power from technically feasible renewable energy technologies. 
Diab (1995) describes a significant band of coastal land area along South Africa's long coastline with desirable good wind power generation potential. There are also federal and provincial government incentives, besides an established clear Power Purchase Agreement, to encourage investment in the wind energy sector (Global Wind Energy Council, 2011). Nevertheless, there is a growing presence of international wind power providers such as Vestas, Enercon, Siemens, Goldwind, and Juwi. A measured entry through agreements with Provincial Governments, while retaining the capacity and flexibility to quickly ramp up production after gaining access to high volume projects, may be a useful approach in South Africa.

\section{CONCLUSIONS}

In this paper we have presented the entrepreneurial opportunity as a means of exploring and evaluating how wind energy markets might affect the opportunities (Dunning and Lundan, 2008) of entrepreneurship in the three emerging economies. Developing countries have an important role in the efforts to stop global warming. While the international climate negotiations have failed to deliver new accomplishments for the reduction of carbon emissions, national policies and measures have made significant progress, and the renewable energy market is rapidly changing.

According to Winkler (2006), the usual environmental arguments against wind farms - visual pollution, bird strikes and turbine noise - are somewhat muted by broader considerations such as the noise emission of a wind turbine at $1100 \mathrm{ft}$ distance being $35-45 \mathrm{~dB}$, compared with that of a car traveling at $40 \mathrm{mph}(55 \mathrm{~dB})$ or a heavy-duty truck $(65 \mathrm{~dB})$. Thus, various governmental or private sector-led wind energy initiatives have emerged around the world. Nevertheless, the fact that location efficiencies for production and consumption might be different implies that cross-nation perspectives need to be considered together within this entrepreneurial opportunity. Johansen and Knight (2010) indicated that smaller firms may rely on an international entrepreneurial orientation in an attempt to optimize their performance.

The countries within the scope of this study include Brazil, China, and South Africa. These countries are selected for the purpose of representing different regions in the world with similar emerging economies. This research focuses on a wide range of aspects for a thorough comparison of the wind energy market conditions in each country for enterprises. Analyzing entrepreneurial and economic aspects of wind power markets are an essential technique for understanding the dynamics of business development in the emerging economy contexts. Doing business in another country is similar to understanding guanxi anywhere, as it takes a significant amount of effort 
to understand the characteristics of the market that prevail in the place of future enterprise. A new global enterprise needs to have a firm grasp on the main challenges and advantages for renewable energy sources in a new market; a clean electric array where environment and economic benefits are incalculable. Hence, the effort will pay off as Brazil, China, and South Africa are growing in the right direction.

\section{IMPLICATIONS}

The discussions of this study provide valuable suggestions and implications for governments and national leaders in understanding the present status and country differences among entrepreneurial opportunity, challenges, as well as benefits, costs, and risks in the global wind power markets, particularly in Brazil, China, and South Africa.

\section{Implications for practice}

Firstly, institutional entrepreneurship is a crucial component in the transformation from a developing country to a developed country (Gilley and Maycunich, 2000; Peng, Wang, and Jiang, 2008). In addition, institutional entrepreneurship has the potential for being a valued component by contributing to entrepreneurial development and economic competitiveness. For this reason, institutional entrepreneurship appears to be important not only for businesses, but also for countries. For practical applications, instilling more institutional entrepreneurship through entrepreneurial opportunities may lead to more desired outcomes for wind energy businesses and emerging countries.

Secondly, political, legal, and economic systems in the global environment appear to be beneficial when a country promotes entrepreneurial opportunities and activities. Entrepreneurial opportunities may help a country in integrating its vision, mission, strategy, and practices. Thus, implementing these entrepreneurial opportunities may encourage people and businesses to create innovation and practical performance for national and global societies.

Thirdly, the cross-country comparison in Table 3 is useful, but the results in the negative column offer insights that are mostly known in the international business and entrepreneurship area. They are mostly macroenvironment related and have very little implication regarding sector-specific effects. The assessment may be undertaken in the future at two levels. At the general level, it will sum up the generic barriers to conducting international business as it is done in the article; at the sector specific level, it will highlight 
the main factors negatively influencing establishing operations in each of the selected countries.

\section{Implications for future study}

Firstly, there is a need to perform an approach and to develop an institutional analysis of country attractiveness in reflection of the complexity of the political, legal and economic systems in the selected countries. The development of institutional framework would also allow additional countries to be added into the list as the research expands. Engaging in cross-border business activity provides many entrepreneurial opportunities for the creation and exploitation of new institutional forms (Dunning and Lundan, 2008). We believe that institutional analysis will offer great promise for reinvigorating many areas of international business research by providing the intellectual tools that allow scholars to confront the complexities that characterize the contemporary global economy (Dunning and Lundan, 2008).

Secondly, there is a need for the future study to integrate the research framework with Porter's five forces model and other existing related research which analyze competition in the wind energy industry. Issues such as new entrants, substitutes, and suppliers will also be interesting for consideration in the future.

Finally, in addition to the emerging wind power markets in Brazil, China, And South Africa, there is a need to consider the whole wind energy industry in the other emerging markets for future study. Those emerging countries include India, Malaysia, Mexico, Russia, and others. Furthermore, using reliable and valid measurements and methodologies to conduct the related researches in the other developing and developed countries will be of interest for future study.

\section{Acknowledgments}

The author would like to thank two anonymous reviewers for providing their insightful comments and suggestions to improve the quality of this paper.

\section{References}

Acs, Z. J., \& Virgill, N. (2010). Entrepreneurship in developing countries. In Z.

J. Acs \& D. B. Audretsch (Eds), Handbook of Entrepreneurship Research (pp. 485-515). New York: Springer.

Ansay, T., \& Wallace, D. (2011). Introduction to Turkish Law. Netherlands: Kluwer Law International. 
Ardichvili, A., Cardozo, R., \& Ray, S. (2003). A theory of entrepreneurial opportunity identificiation and development. Journal of Business Venturing, 18(1), 105-123.

Asif, M., \& Muneer, T. (2007). Energy supply, its demand and security issues for developed nad emerging economies. Renewable and Sustainable Energy Reviews, 11(7), 1388-1413.

Bjørnskov, C., \& Foss, N. J. (2008). Economic freedom and entrepreneurial activity: Some cross-country evidence. Public Choice, 134(3-4), 307-328.

Brasil, F. (2010). Fatores perspectivas de emprego [Job Perspectives Factors]. Retrieved from http://www.revistafator.com.br.

Brazilian Wind Energy Association (2011). Retrieved from http://www. abeeolica.org.br.

Brinkman, R. (1995). Economic growth versus economic development: Towards a conceptual clarification. Journal of Economic Issues, 29(4), 1171-1188.

Brush, C. G., Greene, P. G., Hart, M. M., \& Haller, H. S. (2001). From initial idea to unique advantage: The entrepreneurial challenge of constructing a resource base. The Academy of Management Executive, 15(1), 64-80.

Chen, Y. F., \& Lai, M. C. (2010). Factors influencing the entrepreneurial attitude of Taiwanese tertiary-level business students. Social Behavior and Personality, 38(1), 1-12.

Chrysostome, E. (2010). The success factors of necessity immigrant entrepreneurs: In search of a model. Thunderbird International Business Review, 52(2), 137-152.

Diab, R. (1995). Wind atlas of South Africa, Pretoria, South Africa: Department of Minerals and Energy.

Drucker, P. F. (2001). Management challenges for the $21^{\text {st }}$ century. New York: HarperCollins Publishers.

Dunning, J. H., \& Lundan, S. M. (2008). Institutions and the OLI paradigm of the multinational enterprise. Asia Pacific Journal of Management, 25(4), 573-593.

Eckhardt, J. T., \& Shane, S. A. (2003). Opportunities and entrepreneurship. Journal of Management, 29(3), 333-349.

Fattah- Abdel, D. (2011). Access roads for wind farms reveal hidden costs of going green. Hurriyet Daily News. Retrieved from http://www. windturbines.net/news/Access-roads-for-wind-farms-reveal-hiddencosts-of-going-green-Hurriyet-Daily-News-djt.

Federico, C. (2009). China's cleantech landscape: The renewable energy technology paradox. Retrieved from http://eprints.ucl. ac.uk/16051/1/16051.pdf.

Floyd, D., \& McManus, J. (2005). The role of SMEs in improving the competitive position of the European Union. European Business Review, 17(2), 144150.

Frankenstein, J. (2011). China: Getting beyond the headlines. Thunderbird International Business Review, 53(4), 423-434. 
Global Wind Energy Council. (2011). Global Wind Report 2010. Retrieved from http://www.gwec.net/fileadmin/images/Publications/GWEC_ annual_market_update_2010_-_2nd_edition_April_2011.pdf.

Gow, D. (2009). Wind power becomes Europe's fastest growing energy source. Retrieved from http://www.guardian.co.uk/environment/2009/feb/03/ wind-power-eu.

Hill, C. W. L. (2011). Global business today. $7^{\text {th }}$ ed. New York: McGraw-Hill/ Irwin.

Hindle, K. (2004). A practical strategy for discovering, evaluating, and exploiting entrepreneurial opportunities: research-based action guidelines. Journal of Small Business and Entrepreneurship, 17(4), 267-276.

Johansen, D., \& Knight, G. (2011). Entrepreneurial and market-oriented SMS's fit to international environments, dynamic, capacities and competencies. International Business: Research, Teaching and Practice, 4(1), 38-54.

Kelley, D. J., Bosma, N., \& Amarós, J. E. (2011). Global Entrepreneurship Monitor: 2010 Global Report. Babson Park MA: Babson College, Universidad del Desarrollo, and Landon Business School.

Kirsten, M., \& Rogerson, C. M. (2002). Tourism, business linkages and small enterprise development in South Africa. Development Southern Africa, 19(1), 29-59.

Klein, P. G. (2008). Opportunity discovery, entrepreneurial action, and economic organization. Strategic Entrepreneurship Journal, 2(3), 175190.

Kroldrup, L. (2010). Gains in global wind capacity reported. Retrieved from http://green.blogs.nytimes.com/2010/02/15/gains-in-global-windcapacity-reported/.

Landstrom, H. (2005). Pioneers in entrepreneurship and small business research. New York: Springer.

Lazear, E. M. (2002). Entrepreneurship. NBER working paper No. 9109.

Lema, A., \& Ruby, K. (2006). Towards a policy model for climate change mitigation: China's experience with wind power development and lessons for developing countries. Energy for Sustainable Development, 10(4), 5-13.

Leung, T. K. P., \& Wong, Y. H. (2001). The ethic and positioning of guanxi in China. Marketing Intelligence \& Planning, 19(1), 55-64.

Li, H., \& Zhou, L. A. (2005). Political turnover and economic performance: the incentive role of personnel control in China. Journal of Public Economics, 89(9-10), 1743-1762.

Li, J., Shi, P., \& Gao, H. (2010). 2010 China wind power outlook. Retrieved from http://www.gwec.net/fileadmin/documents/test2/wind\%20report0919.pdf

Lieberthal, K. (1995). Governing China: From revolution through reform. New York: W. W. Norton.

Lumpkin, G. T. (2011). From legitimacy to impact: Moving the field forward by asking how entrepreneurship informs life. Strategic Entrepreneurship Journal, 5(1), 3-9. 
Marques, J., Pinheiro, H., Gründling, H. A., Pinheiro, J. R., \& Hey, H. L. (2003). A survey on variable-speed wind turbine system. Retrieved from http:// www.ufsm.br/gepoc/publicacoes/congressos/A\%20Survey\%20on\%20 Variable-Speed\%20Wind\%20Turbine\%20System.pdf.

McKinsey (2010). Lions on the Move: Progress and Potential of African Economies. Retrieved from http://www.mckinsey.com/mgi/publications/ progress_and_potential_of_african_economies/pdfs/MGI_african_ economies_ExecSumm.pdf.

McMullen, J. S., Plummer, L. A., \& Acs, Z. J. (2007). What is an entrepreneurial opportunity? Small Business Economics, 28(4), 273-283.

Ministry of Mines and Energy (2008a). O Brasil e as fontes renováveis de energia [The Brazil and its energy souces]. Brasília, Brazil. Retrieved from http://www.mme.gov.br.

Ministry of Mines and Energy (2008b). Empresa de Pesquisa Energética [Energy Research Company]. Brasília, Brazil. Retrieved June 8, 2011, from http:// www.epe.gov.br.

Ministry of Mines and Energy (2008c). Leilão de Eólica [Auction Wind]. Brasília, Brasil. Retrieved from http://www.mme.gov.br.

Ministry of Mines and Energy (2008d). Programa de Incentivo a Fontes Altenativas [Alternative Sources Incentive Program]. Brasília, Brazil. Retrieved June 3, 2011, from http://www.epe.gov.br.

Muylaert de Araújo, M. S., \& Vasconcelos de Freitas, M. A. (2008). Acceptance of renewable energy innovation in Brazil - case study of wind energy. Renewable and Sustainable Energy Reviews, 12(2), 584-591.

Nonis, S. A., \& Relyea, C. (2012). Business innovations from emerging market countries into developed countries: Implications for multinationals from developed countries. Thunderbird International Business Review, 54(3), 291-298.

Oksenberg, M. (2001). China's political system: Challenges of the twenty-first century. The China Journal, 45, 21-35.

Palich, L. E., \& Bagby, D. R. (1995). Using cognitive theory to explain entrepreneurial risk-taking: Challenging conventional wisdom. Journal of Business Venturing, 10(6), 425-438.

Pecequilo, C. S. (2008). Brazil's foreign policy in the 21st century: the combining axis of horizontal and vertical multilateral cooperation. Revista Brasileira de Política International, 51(2): 136-153.

Pereira, A. O. Jr., Pereira, A. S., Rovere E. L. L., Barata, M. M. de L., Villar, S. de C., \& Pires, S. H. (2011). Strategies to promote renewable energy in Brazil. Renewable and Sustainable Energy Reviews, 15(1), 681-688.

Peng, M. W., Wang, D. Y. L., \& Jiang, Y. (2008). An institution-based view of international business strategy: a focus on emerging economies. Journal of International Business Studies, 39, 920-936.

Porter, M. E. (1990). Competitive advantage of nations. New York: Free Press. 
Potter, P. B. (1999). The Chinese legal system: Continuing commitment to the primacy of state power. The China Quarterly, 159, 673-683.

Rodie, A. R., \& Martin, C. L. (2001). Competing in the service sector - The entrepreneurial challenge. International Journal of Entrepreneurial Behaviour \& Research, 7(1), 5-21.

Rosas, P., Pereira, A., Aquino, R., \& Guimarães, R. (2004). Study of impacts of a large penetration of wind power and distributed power generation as a whole on the Brazilian power system. Retrieved from http:// www.2004ewec.info/files/23_1400_pedrorosas_01.pdf.

Scott, W. R. (1995). Institutions and organizations. Thousand Oaks, CA: Sage. Shane, S., \& Venkataraman, S. (2000). The promise of entrepreneurship as a field of research. Academy of Management Review, 25(1), 217-226.

Singh, R. P. (2001). A comment on developing the field of entrepreneurship through the study of opportunity recognition and exploitation. The Academy of Management Review, 26(1), 10-12.

Stephan, U., \& Uhlaner, L. M. (2010). Performance-based vs. socially supportive culture: A cross-national study of descriptive norms and entrepreneurship. Journal of International Business Studies, 41, 13471364.

Swartz, S., \& Oster, S. (2010). China tops U.S. in energy use. Retrieved from http://online.wsj.com/article/SB1000142405274870372050457537671 2353150310.html?mod=djemalertNEWS.

Timmons, J. A., \& Spinelli, S. (2009). New venture creation: entrepreneurship for the 21st century. New York, NY: McGraw-Hill/Irwin.

The World Bank. (2011). China quick facts. Retrieved from http://web. worldbank.org/WBSITE/EXTERNAL/COUNTRIES/EASTASIAPACIFICEXT/C HINAEXTN/0,,contentMDK:20680895 pagePK:1497618 piPK:217854 t heSitePK:318950,00.html.

Transparency International. (2010). Corruption Perception Index 2010. Retrieved from http://www.transparency.org.

Tsang, E. W. K. (1998). Can guanxi be a source of sustained competitive advantage for doing business in China? The Academy of Management Executive, 12(2), 64-73.

United Nations Environmental Program. (2011). Wind Fact Sheet. Retrieved from http://www.unep.fr/energy/information/publications/factsheets/ pdf/wind.PDF.

Venkataraman, S. (1997). The distinctive domain of entrepreneurship research: An editor's perspective. In J. Katz \& R. Brockhaus (Eds), Advances in entrepreneurship, firm emergence and growth (pp. 119138). Greenwich, CT: JAI Press.

Von Schnitzler, A. (2008). Citizenship prepaid: Water, calculability, and technopolitics in South Africa. Journal of Southern African Studies, 34(4), 899917.

Wennekers, S., \& Thurik, R. (1999). Linking entrepreneurship and economic growth. Small Business Economics, 13(1), 27-56. 
Whiting, S. (2001). Power and wealth in rural China: The political economy of institutional change. Cambridge, UK: Cambridge University Press.

Winkler, H. (2006). Energy policies for sustainable development in South Africa. South Africa: Energy Research Center, University of Cape Town.

World Economic Forum. (2010). The Global Competitiveness Report 20102011. Geneva, Switzerland: World Economic Forum.

World Trade Organization. (2011). Annual report 2011. Retrieved from http:// www.wto.org/english/res_e/booksp_e/anrep_e/anrep11_e.pdf.

Zahra, S. A., Abdelgawad, S. G., \& Tsang, E. W. K. (2011). Emerging multinationals venturing into developed economies: Implications for learning, unlearning, and entrepreneurial capability. Journal of Management Inquiry, 20(2), 1-8.

\begin{abstract}
Polish)
Energia pochodzqca z wiatru jest postrzegana jako ważne źródło czystej, odnawialnej energii i realny sposób obniżenia poziomu emisji gazów cieplarnianych. Niniejszy artykuł oferuje przegląd możliwości i wyzwań stojqcych przed rozwijajqcymi się rynkami energii z wiatru w Brazylii, Chinach i RPA. Praca przedstawia także konkretne informacje dotyczqce systemów kulturowych i prawnych jak również warunków ekonomicznych w tych rozwijajqcych się państwach. Dane pochodzq z Global Entrepreneurship Monitor, Banku Światowego, the Global Wind Report oraz innych publicznie dostępnych źródet. Praca proponuje schemat analityczny do analizy relacji pomiędzy okazjami przedsiębiorczymi firm działajqcych $w$ sektorze energii wiatrowej, a korzyściami, kosztami i ryzykiem typowymi dla danego kraju. Celem badania była prezentacja praktycznego modelu, który porównuje korzyści, koszty oraz czynniki ryzyka, jak również szanse i wyzwania w trzech krajach rozwijajqcych się. Badanie rozpoczyna się od analizy efektywności gospodarek w trzech krajach i podkreślenia znaczenia korzyści, kosztów i czynników ryzyka dla tych państw. Następnie scharakteryzowane zostanq szanse $i$ wyzwania dla trzech wybranych państw. Wreszcie oferujemy wnioski i praktyczne implikacje użyteczne $w$ dalszych badaniach. Badania pozwalaja wyciqgnać wnioski, iż Brazylia, Chiny i RPA oferujq różne perspektywy rozwoju dla firm z branży energii pochodzqcej z wiatru. Poprawa szans dla przedsiębiorców stanowi dobry sposób na pokonanie wyzwań stojq̨cych przed rozwojem nowych firm na rynkach państw rozwijajqcych się.
\end{abstract}

Słowa kluczowe: Gospodarki państw rozwijajqcych się, kraje z efektywnq gospodarkq, rynki energii wiatrowej, energia ze źródeł odnawialnych, okazje przedsiębiorcze.

\title{
Biographical note
}

Dr. Chien-Chi Tseng is an Assistant Professor in the School of Business and Management at Morgan State University. He received his Ph.D. degree from the University of Minnesota in 2010 and completed a Post-Doctoral Business Program at the University of Florida in 2011. He has 16 years of experience for teaching, research, and professional background in entrepreneurship 
related area. His research interests focus on a broad range of topics in entrepreneurship with relationships among business innovation, economic development, entrepreneurial opportunity, entrepreneurial performance, global entrepreneurship, organizational learning practices, and organizational learning. He can be reached at: chien-chi.tseng@morgan.edu. 